\title{
A Case of Schwannoma Located in the External Auditory Canal
}

\author{
Seong Kyeong Yang, Jong Cheol Lee, Dan Bi Shin, and Joong Keun Kwon \\ Department of Otolaryngology-Head and Neck Surgery, Ulsan University Hospital, University of Ulsan College of Medicine, Ulsan, Korea
}

\section{외이도에 발생한 신경초종 1예}

양성경 · 이종철 · 신단비 · 권중근

울산대학교 의과대학 울산대학교병원 이비인후과학교실

\author{
Received February 28, 2015 \\ Revised May 25, 2015 \\ Accepted June 2, 2015 \\ Address for correspondence \\ Joong Keun Kwon, MD, PhD \\ Department of Otolaryngology- \\ Head and Neck Surgery, \\ Ulsan University Hospital, \\ University of Ulsan \\ College of Medicine, \\ 877 Bangeojinsunhwando-ro, \\ Dong-gu, Ulsan 44033, Korea \\ Tel $+82-52-250-7180$ \\ Fax $+82-52-234-7182$ \\ E-mail kwonjk@live.co.kr
}

Schwannoma is slowly-growing, benign tumor that originates from the schwann cell and is rarely found in the external auditory canal (EAC). In this article, we describe a 30-year-old female patient with $12 \times 7 \times 4 \mathrm{~mm}$ EAC schwannoma located between the helical crura and tragus of the left ear. The schwannoma was easily removed by local excision. We discuss the differential diagnosis, clinical and histologic features, and treatment of EAC schwannoma.

Korean J Otorhinolaryngol-Head Neck Surg 2015;58(9):650-3

Key Words Ear canal · Neurilemmoma.

\section{서 론}

신경초종(Schwannoma)은 말초신경의 수초를 만드는 슈반 세포(Schwann cell)에서 기원하는 양성종양으로 몸 안의 말 초신경 어디에서나 발생 가능하다. 신경초종의 약 $25 \%$ 정도 가 두경부 영역에서 발생하는 것으로 알려져 있으나, ${ }^{1)}$ 외이도 에서 기원하여 외이도 종물로 발견된 경우는 매우 드물다. 저 자들은 외이도 입구의 종물을 주소로 내원한 환자에서 외이 도 신경초종 1 예를 경험하였기에 문헌고찰과 함께 보고하는 바이다.

\section{증 례}

30세 여자 환자로 6개월 전 우연히 발견된 좌측 외이도 종 물을 주소로 내원하였다. 환자는 외국 거주 중 좌측 귓볼의 켈 로이드 치료를 위해 외국 현지 병원에서 병소 내 스테로이드 주
입술을 시행받았다. 당시 좌측 외이도 입구의 종물이 같이 발 견되었으며 이루, 이통, 감각이상, 난청 등 자각 증상은 없었다. 현지 병원에서 절개생검과 두경부 자기공명영상(MRI)을 시행 하였고 병리조직검사 결과지는 신경초종에 합당하다고 기록되 어 있었다. MRI T1 강조영상에서 $13 \times 8 \mathrm{~mm}$ 크기의 조영 증강 되는 종물이 좌측 외이도에서 관찰되었다(Fig. 1). 환자는 종 물에 대한 완전 절제를 원해 본원을 방문하였다.

내원 당시 좌측 이주와 이륜각 사이에 매끈한 표면의 과각 화된 연분홍색 종물이 관찰되었고, 이전 절개생검으로 인해 크기는 작았다(Fig. 2). 이내시경 검사상 외이도가 좁아지거 나 외이도염의 소견은 없었고 고막은 정상이었다. 국소마취 하에 수술현미경을 이용하여 경외이도 접근법으로 종물을 완전 절제하였다. 종물은 피막에 잘 싸여진 채 외이도 연골로부 터 순조롭게 박리되었으며, 중이 구조물이나 고막과 연결되어 있지 않았다(Fig. 3). 병리조직검사상 $12 \times 7 \mathrm{~mm}$ 의 종물로 hematoxylin \& eosin 염색에서 상호 교차하는 작은 다발형태의 방 

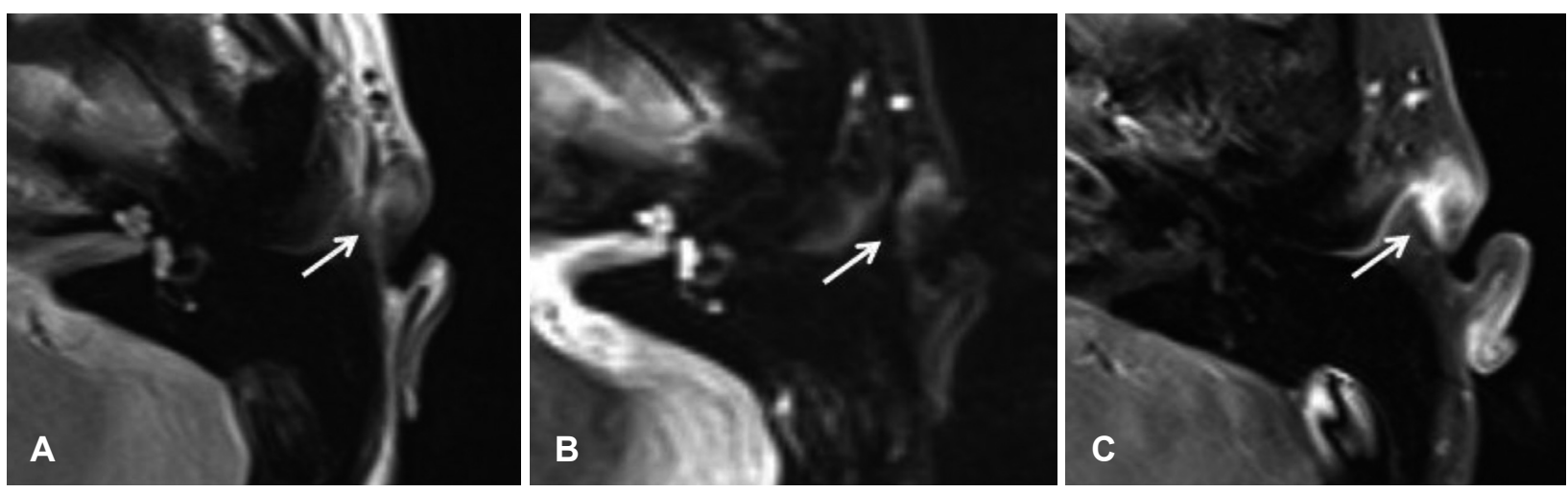

Fig. 1. Axial magnetic resonance imaging. T1-weighted image shows focal iso-signal mass (arrow) at the left external auditory canal (A). T2-weighted image shows slightly low signal intensity and heterogeneous mass (arrow) at the left external auditory canal wall (B). Gadolinium-enhanced, T1-weighted image shows well enhanced mass (arrow) at the left external auditory canal with no bony erosion and no middle ear involvement $(C)$.
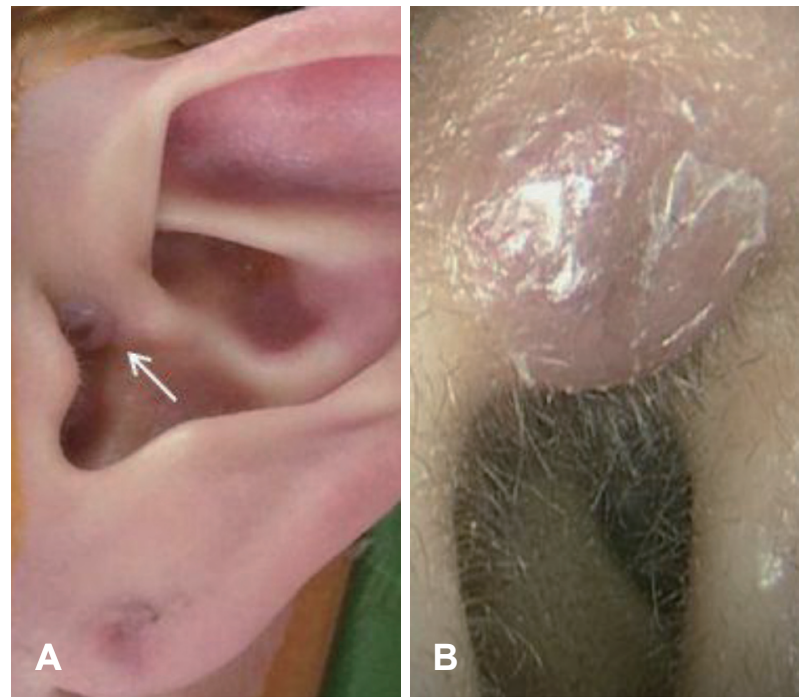

Fig. 2. Pale pinkish mass with smooth surface (arrow) located between helical crura and tragus of left ear (A). Enlarged view of the mass at the roof of meatus (B).

추체 세포들이 관찰되었다. 면역조직화학염색에서 S-100 protein에 양성반응을 보이는 신경초종으로 확진되었다(Fig. 4).

수술 당일 퇴원 후 회복 기간 동안 별 다른 합병증은 관찰되 지 않았으며 술 후 5개월간 재발은 없었다.

\section{고 찰}

신경초종은 서서히 자라는 신경기원의 양성종양이다. 이과 영역에서는 청신경초종이 가장 흔하나, 중이강 내에서도 안 면신경, 고삭신경, 설인신경의 고실분지(Jacobson's nerve)에 서 기원하는 신경초종이 드물게 발견된다.2)

신경초(nerve sheath) 안에서 기원하기 때문에 신경다발막 (perineurium)으로 구성된 진성 피막을 가지며 주변 조직으로 침투하지 않는 특성이 있다. 이개의 감각은 대이개신경(great

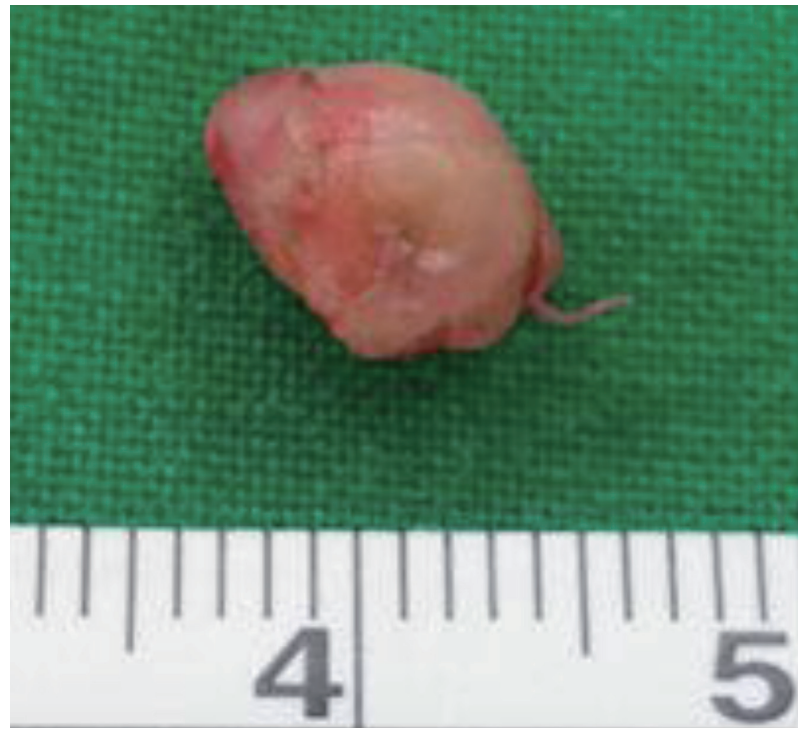

Fig. 3. A well-encapsulated tumor removed en bloc (scale, $12 \times 7 \times$ $4 \mathrm{~mm})$.

auricular nerve)이 지배하며, 외이도의 전상부는 하악신경(mandibular nerve)의 이개측두분지(auriculotemporal branch)가 지배한다. 본 증례의 경우 이주와 이륜각 사이에서 발견되었 으므로 대이개신경이나 하악신경의 이개측두분지에서 기원한 신경초종으로 추정된다.

문헌 고찰을 토대로 살펴 보면 외이도 신경초종의 발견 연령 은 4 69세, 크기는 4 35 mm 정도로 다양하였으며 기시 부위 는 외이도 후벽이 가장 많았으나 전, 상, 하벽 모두 발생할 수 있 다. 전체 환자의 $2 / 3$ 에서는 난청을 호소하였으며, 기타 이통, 혈성 이루 등 재발성 외이도염의 증상을 유발하기도 하며 본 증례처럼 외이도 폐색 증상 없이 단순한 외이도 종물로 발견 되기도 한다(Table 1). ${ }^{2-12)}$ 신경 기원의 종양이지만 신경통이나 감각 이상 등은 드물다.

섬유종, 연골종, 평활근종(leiomyoma) 등 다른 연부 조직 

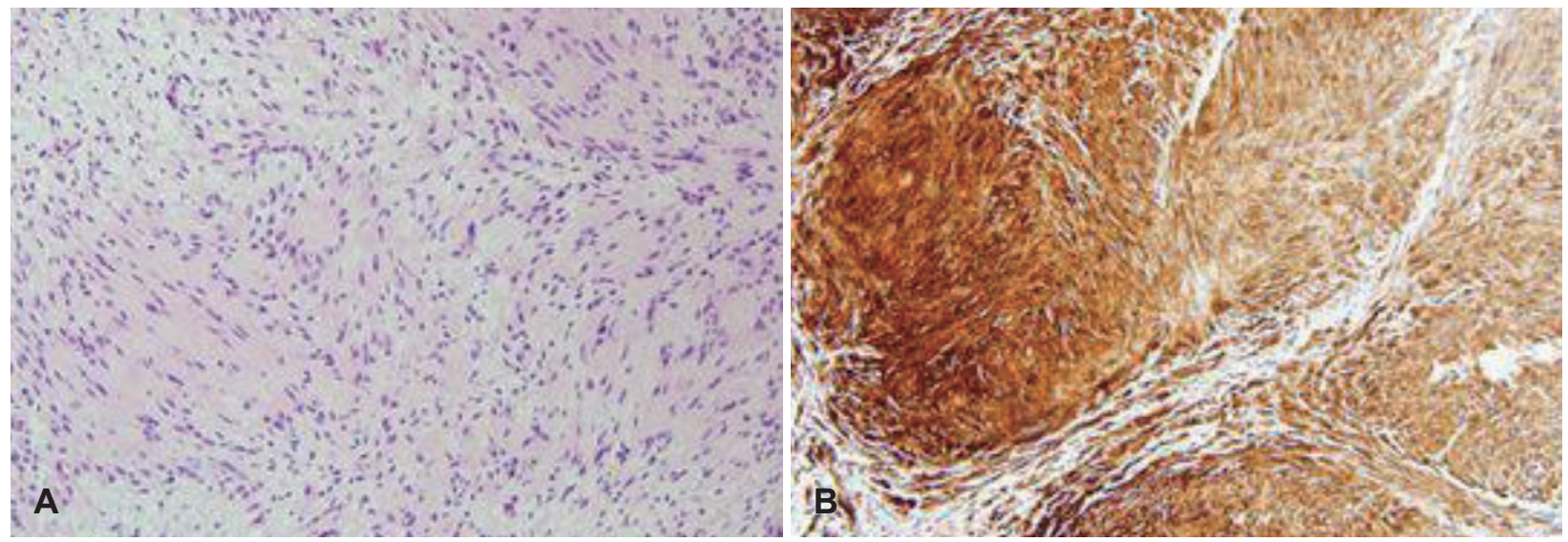

Fig. 4. Histopathological section. The tumor is composed of wavy spindle cells and meshwork of gelatinous and microcystic tissue. This section shows loosely organized hypocellular Antoni-B area (H\&E, ×200) (A). Immnuohistochemistry for S-100 was positive in cytoplasm and nuclei $(\times 200)(B)$.

Table 1. Characteristics of schwannoma of EAC

\begin{tabular}{|c|c|c|c|c|c|c|}
\hline Authors & Sex & Age & Origin* & Symptoms & Size & Approach \\
\hline Chung, et al. $\left.{ }^{2}\right)$ & M & 4 & Post/sup & EAC mass & $(-)$ & $(-)$ \\
\hline Wu, et al. ${ }^{3)}$ & M & 50 & $(-)$ & Pain/bloody otorrhea & $10 \mathrm{~mm}$ & Retroauricular \\
\hline Lewis, et al. ${ }^{4)}$ & M & 45 & $(-)$ & External otitis & $16 \mathrm{~mm}$ & $(-)$ \\
\hline Harcourt and Tungekar ${ }^{5)}$ & M & 28 & Post/sup & Hearing loss/bloody otorrhea & $(-)$ & Retroauricular \\
\hline Lee, et al. $\left.{ }^{6}\right)$ & M & 25 & $(-)$ & Earfullness & $20 \mathrm{~mm}$ & \\
\hline Kim, et al..$^{7}$ & $\mathrm{~F}$ & 69 & Sup & Hearing loss & $18 \mathrm{~mm}$ & $(-)$ \\
\hline (2 cases) & $\mathrm{F}$ & 36 & Post & Hearing loss & $22 \mathrm{~mm}$ & Retroauricular \\
\hline Galli, et al. ${ }^{8)}$ & M & 63 & $(-)$ & EAC mass & $30 \mathrm{~mm}$ & Endaural \\
\hline Gross, et al. ${ }^{9}$ & M & 44 & Post/inf & Hearing loss/external otitis & $11.5 \mathrm{~mm}$ & Endaural \\
\hline Morais, et al. ${ }^{10)}$ & $\mathrm{F}$ & 55 & Roof & Incidental finding & $4 \mathrm{~mm}$ & Endaural \\
\hline Topal, et al. ${ }^{11)}$ & $\mathrm{F}$ & 51 & Post & Hearing loss/external otitis & $17 \mathrm{~mm}$ & Endaural \\
\hline Magliulo, et al. ${ }^{12)}$ & M & 20 & Ant/inf & Hearing loss & $(-)$ & Retroauricular \\
\hline This case & $\mathrm{F}$ & 30 & Roof & EAC mass & $12 \mathrm{~mm}$ & Endaural \\
\hline
\end{tabular}

$(-)$ means that information was not available. *lindicates the sides of ear canal wall. EAC: external auditory canal

종양과 감별진단이 필요하다. 외이도 신경초종은 주위 조직 으로 침투하지 않으며 정상피부로 덮여 있는 단단하고 매끈 한 종물로 출혈, 색소침착, 궤양 등의 소견이 없으나 확진을 위해 병리조직 검사가 필요하며 면역조직화학 검사가 도움이 된다. 신경초종의 주요 병리소견은 길쭉한 핵을 가진 방추체 세포의 집합체들이 일렬로 늘어선 것이다. 세포가 밀집한 부 위를 Antoni-A 지역, 세포가 듬성듬성하여 불규칙하게 배열 된 부위를 Antoni-B 지역이라고 한다. 신경초 세포에서 기원 한 종양은 S-100 단백질을 이용한 면역조직화학염색에서 세 포질과 핵이 염색되는 양성소견을 보이고, 데스민(desmin)이나 평활근액틴(smooth muscle actin, SMA)을 이용한 면역조직화 학염색에서는 음성소견을 보인다. 반면 병리조직학적으로 감 별해야 할 신경섬유종은 피막으로 둘러싸여 있지 않고 Antoni-A, Antoni-B 패턴이 없으며 평활근종은 SMA에는 양 성, S-100에는 음성소견을 보이고 섬유조직형성흑색종(des- moplastic melanoma)은 S-100에 양성이나 Antoni-A, Antoni-B 패턴을 보이지 않는다.,13)

외이도가 폐색되어 이내시경으로 외이도 내측을 관찰할 수 없을 경우 MRI, CT scan 등의 영상 검사도 종물의 범위 및 특 성을 파악하고 향후 치료 계획을 세우는 데 유용하다.

치료는 완전 절제로 국소 재발은 매우 드문 것으로 알려져 있 다. 본 증례에서도 경외이도 접근법을 통한 완전 제거 후 5 개월 간 재발의 소견은 없었다.

\section{REFERENCES}

1) Leu YS, Chang KC. Extracranial head and neck schwannomas: a review of 8 years experience. Acta Otolaryngol 2002;122(4):435-7.

2) Chung TI, Park KH, Shim SY. A case of neurilemmoma of the external ear canal. Korean J Otolaryngol 1978;21(1):65-7.

3) Wu CM, Hwang CF, Lin CH, Su CY. External ear canal schwannoma: an unusual case report. J Laryngol Otol 1993;107(9):829-30.

4) Lewis WB, Mattucci KF, Smilari T. Schwannoma of the external auditory canal: an unusual finding. Int Surg 1995;80(3):287-90. 
5) Harcourt JP, Tungekar MF. Schwannoma of the external auditory canal. J Laryngol Otol 1995;109(10):1016-8.

6) Lee SM, Park SY, Lee YW, Lee SH, Chi CH. A case of neurilemmoma of the external auditory canal. Korean J Otolaryngol 1996;39(2): 301-5.

7) Kim YK, Chung KH, Kim JH, Yoon YJ. Two cases of neurilemmoma of the external auditory canal. Korean J Otolaryngol 1996;39(5):870-4.

8) Galli J, d'Ecclesia A, La Rocca LM, Almadori G. Giant schwannoma of external auditory canal: a case report. Otolaryngol Head Neck Surg 2001;124(4):473-4.

9) Gross M, Maly A, Eliashar R, Attal P. Schwannoma of the external auditory canal. Auris Nasus Larynx 2005;32(1):77-9.

10) Morais D, Santos J, Alonso M, Ovelar Y. [Schwannoma of the external auditory canal: an exceptional location]. Acta Otorrinolaringol Esp 2007;58(4):169-70.

11) Topal O, Erbek SS, Erbek S. Schwannoma of the external auditory canal: a case report. Head Face Med 2007;3:6.

12) Magliulo G, Ciniglio Appiani M, Colicchio MG, Pulice G, Di Gioia CR. Schwannoma of the external auditory canal. Otol Neurotol 2012; 33(2):e13-4.

13) Busam KJ. Desmoplastic melanoma. Clin Lab Med 2011;31(2):321-30. 